\title{
Effect of plant age and sowing density on nitrogen fixation of Medicago truncatula at 2 different dates of sowing
}

\author{
ABK Dahmane 1, RD Graham 2 \\ 1 INAT, Agronomy Laboratory, 43, Avenue Charles Nicolle 1082, Tunis, Tunisia; \\ 2 Wari, Department of Agronomy, University of Adelaide, Glen Osmond, 5064 SA, Australia
}

(Received 21 February 1993; accepted 20 July 1993)

\begin{abstract}
Summary - An acetylene reduction (AR) assay was used to measure nitrogenase activity of soil cores as an estimate of the rate of nitrogen $\left(\mathrm{N}_{2}-\right)$ fixation in nodulated Medicago truncatula cv Jemalong in the field on several occasions during the growing season. The effects of date of sowing and of varying the density of sowing from 0 to $1000 \mathrm{~kg}$ $\mathrm{ha}^{-1}$ seed were investigated. Results showed an increase in AR activity with increasing medic sowing densities during the vegetative period of plant growth, whereas towards maturity AR activity was slightly higher at low than at medium or high densities. Soil core AR activity was better correlated with the weight of shoot dry matter (DM) present at the time of harvest during the vegetative period of plant growth than after flowering. At all sowing densities and irrespective of sowing date, AR activity increased from sowing to full flowering and thereafter decreased rapidly. The postflowering decline in AR activity was sharper at the high than at the lower densities and coincided with a marked decrease in plant population in the medium and high-sowing density treatments. The relations between AR activity, shoot dry weight and plant number per unit area in the pre-flowering and post-flowering periods were examined via linear regression analysis.
\end{abstract}

acetylene reduction / Jemalong / medic / soil core / $\mathrm{N}_{2}$-fixation / sowing density

Résumé - Effet de l'âge des plantes et de la densité de semis sur la fixation de l'azote par Medicago truncatula à 2 dates de semis. La technique de la réduction de l'acétylène a été utilisée pour mesurer, à différentes occasions durant la saison de culture, l'activité nitrogénasique chez les racines nodulées du cultivar Jemalon (Medicago truncatula) semé en plein champ à différentes densités ( 0 à $1000 \mathrm{~kg} \mathrm{ha}^{-1}$ ) et à deux dates de semis (une précoce et une tardive). La réduction de l'acétylène par les carottes de sol issues des différents traitements montre une meilleure corrélation pendant la période végétative avec la quantité présente de matière sèche des parties aériennes au moment du prélèvement qu'après la floraison. Quelles que soient la date et la densité de semis, la réduction de l'acétylène augmente du semis à la pleine floraison puis diminue par la suite rapidement. La diminution après floraison de l'activité réductrice de l'acétylène est plus importante chez les densités élevées que chez les plus faibles et coïncide avec une forte réduction du nombre de plantes chez les densités moyennes et élevées. Les relations entre l'activité réductrice de l'acétylène des carottes du sol, la matière sèche des parties aériennes de Jemalong et le nombre de plants de Jemalong par unité de surface pendant les périodes pré-floraison et post-floraison ont été examinées au moyen d'une analyse de régression.

réduction de l'acétylène / Jemalong / Medicago truncatula / carottes de sol / fixation de l'azote / densité de semis 


\section{INTRODUCTION}

A field survey of pastures in 1974 (Dahmane, 1978) showed that a high nitrogen (N) status in soil was associated with a high proportion of Medicago spp (medic) in the sward. Although the survey did not include a detailed estimation of the medic population at the time of sampling, the hypothesis generated from the survey results for soil total $\mathrm{N}$ was that the higher the medic population per unit area, the higher the inputs of fixed $\mathrm{N}$ to the soil. So far no studies have been made with medics on the variation in $\mathrm{N}_{2}$-fixation associated with various plant sowing densities. Most studies on $\mathrm{N}_{2}$-fixation in legume-based pastures have concerned an estimation of the annual increment in soil $\mathrm{N}$ under different growth conditions and management practices. A few papers have been published on the rate of $\mathrm{N}_{2}$ fixation by self-regenerating legume pastures throughout the plants life cycle (Brock, 1973; Sinclair, 1974; Halliday and Pate, 1976), but these have involved clovers in pure stands or mixed with grasses. So far no such studies have been made on medics. Since in many Mediterranean climate semi-arid areas where soils are neutral to alkaline, medics are used in ley farming systems to improve soil $\mathrm{N}$ and provide (green) fodder for grazing animals, a more successful use of medic pastures for both purposes can result from determining: a) the effect of plant density on the rate of $\mathrm{N}_{2}$-fixation; and b) the nature of variation in the rate of $\mathrm{N}_{2}$-fixation by medics during the growing season.

A field experiment was conducted to develop a functional relationship between $\mathrm{N}_{2}$-fixation rate in barrel medic (Medicago truncatula) and plant density per unit area by examining the variation in $\mathrm{N}_{2}$-fixation at several stages in the plants life cycle. Nitrogen fixation was estimated by the acetylene reduction (AR) assay.

\section{MATERIALS AND METHODS}

\section{Design and treatment}

An experiment with randomized block design and 4 replications was set up at the Waite Agricultural Research Institute, South Australia. Each replicate consisted of 16 plots. The treatments were factorially combined: a) Sowing densities: seed was sown at 8 different densities, both greater and less than those normally found in practice under field conditions (viz:
$0,1,5,20,50,100,1000 \mathrm{~kg} \mathrm{ha}^{-1}$ seed). The zero density was kept free of any leguminous species; b) sowing dates: April 4 and May 20, 1975. The legume species was Medicago truncatula $\mathrm{c} v$ Jemalong, which was used at both sowing dates. The cultivar Jemalong is here referred to as barrel medic or simply as "medic".

\section{Establishment of the experiment}

The soil in the experimental area was Urrbrae loam classified as a red-brown earth ( $\mathrm{Dr} 2.23$; Northcote, $1971)$ which is acid in the surface horizon $(\mathrm{pH} 5.5-$ 6.0) and alkaline at depth. The total $N$ in the $0-10 \mathrm{~cm}$ depth interval of soil measured over the 4 replications was $0.12 \pm 0.01 \%$. A basal application of $227 \mathrm{~kg} \mathrm{ha}^{-1}$ superphosphate (ie, $50 \mathrm{~kg} \mathrm{ha}^{-1} \mathrm{P}$ ) was made at sowing.

Medic seed was broadcast on a $4.5 \times 2 \mathrm{~m}$ plot which was allocated at random to a treatment within each replication. All seed was inoculated with the commercial Rhizobium meliloti (strain U45) and mixed with a standard rate of superphosphate before broadcasting. To facilitate the distribution of seed and superphosphate over the whole plot area, a slightly humid sand was added to the mixture before sowing.

\section{Measurements}

Plants were harvested several times during the season at $\approx 28$-d intervals (table I). Shoot dry matter (DM) yield and plant population data have been reported by Silsbury et al (1979).

Table I. Rainfall $(\mathrm{mm})$ recorded between sampling periods, dates on which plant dry matter and acetylene reduction measurements were made in the field experiment.

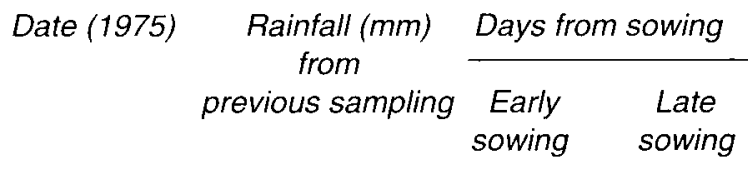

$\begin{array}{lcrr}29-5 & 110^{a} & 55 & - \\ 25-6 & 12 & 82 & 35 \\ 23-7 & 98 & 110 & 63 \\ 21-8 & 73 & 139 & 92 \\ 18-9 & 45 & 167 & 120 \\ 15-10 & 85 & 194 & 147 \\ 12-11 & 70 & 222 & 175\end{array}$

\footnotetext{
a From May 1. Note the dry spell between the first sampling and the second sampling.
} 
For the early sowing treatments 7 samplings were made throughout the growing period, whereas only 6 sampling were taken on the late sown plants (table I). After the second date, both early and late sowings were sampled on the same day. On each of these days harvesting and soil sampling started at 11.30 and finished at $15.30 \mathrm{~h}$.

At each sampling, the number of plants in each subplot (quadrat) was counted and all herbage cut manually at ground level. Immediately after the medic has been harvested, 5 soil cores $(5 \mathrm{~cm}$ in diameter, $10 \mathrm{~cm}$ in depth) were taken from each quadrat and nitrogenase (Nase) activity of the root nodule bacteria was measured by AR assay (Sinclair et al, 1976; Alston and Graham, 1982). The interval between removal of plant tops and introduction of soil cores into the assay incubation jar was $\approx 5 \mathrm{~min}$.

Soils were incubated in 2.2-I glass jars with a rubber-lined screw-type lid a small section of which was removed, exposing the rubber seal. About 0.1 atm acetylene was used for the incubation of soil cores in the presence of air. Once the soil cores (5) were in place in the incubation jar, a wide-mouthed glass vial containing $0.8 \mathrm{~g}$ calcium carbide was introduced into the jar, which was immediately sealed. After removing $10 \%$ of the volume of air present in the jar via a syringe, $10 \mathrm{ml}$ deionized water was added by another syringe to the vial containing the caicium carbide $\left(\mathrm{CaC}_{2}\right)$. The volume of acetylene involved in the reaction of $\mathrm{CaC}_{2}$ and water was equivalent to the volume of air previously removed. From then the time was recorded and the jar put into an insulated box and carried to the laboratory where the ambient temperature was $\approx 20^{\circ} \mathrm{C}$.

Preliminary measurements of the ethylene $\left(\mathrm{C}_{2} \mathrm{H}_{4}\right)$ produced at intervals over a $24-h$ period revealed that after $4 \mathrm{~h}$ the AR rate approached zero. During the first 40 min incubation the rate remained constant. Accordingly a $30-\mathrm{min}$ incubation period was used. At the end of the incubation period, a $0.5 \mathrm{ml}$ gas sample was with drawn from the jar with a new syringe and needle and introduced into a Varian Aerograph series 940 gas chromatograph fitted with a flame inonization detector and a Porapak $\mathrm{R}$ column. The $\mathrm{C}_{2} \mathrm{H}_{4}$ in the sample was determined on the basis of recorder peak heights in comparison to $\mathrm{C}_{2} \mathrm{H}_{4}$ standards, and the $\mathrm{C}_{2} \mathrm{H}_{4}$ in the incubation chamber calculated from the relationships involved.

The AR assay provides only an indirect estimate of $\mathrm{N}_{2}$-fixation over a short interval of time. This constraint limits the use of the technique to comparisons of specific treatments in similar soil and environmental conditions as in the present study, rather than to the determination of integrated seasonal $\mathrm{N}_{2}$ accretion (such caution was also observed by Sinclair et al, 1976). Diurnal variations in Nase activity of this species have been reported by Ruegg and Alston (1978). Integrating $\mathrm{N}_{2}$-fixation over time, even ignoring errors due to hydrogen evolution (Turner and Gibson, 1980), is beyond the scope of this sudy. However, it is worth noting that barrel medic (Medicago truncatula Gaertn) uses a significant proportion (up to $50 \%$ ) of the electron flux for the evolution of $\mathrm{H}_{2}$ (Hopmans et al, 1983). Moreover, Witty and Minchin (1988) stated that addition of acetylene reduces Nase activity due to the acetylene effect on $\mathrm{O}_{2}$ availability for bacteroid respiration. Nevertheless, the AR assay remains a useful technique to obtain rapid and practical information on the functional relationships between the "Environment, plant and rhizobia". This study, as others (Newbould, 1982; Vessey and Patriquin, 1984; Wery et al, 1988) describes variations in nitrogenase activity in relation to potential ground cover by various medic sowing densities, seasonal fluctuations in medic abundance (plant numbers) and plant age.

\section{RESULTS}

\section{Variation in acetylene reduction activity with sowing density}

The results for the early sowing date indicated that there were 3 different aspects of variation in AR activity of soil cores with sowing densities (fig 1, table II): i) during the vegetative period of plant growth (ie, 8, 12 and 16 wk from sowing) AR activity increased with increasing sowing density; ii) at the pod-setting and pod-filling stages (ie, 20 and $24 \mathrm{wk}$ ) AR activity showed no consistent trend with sowing density; iii) towards maturity (ie, 28 and 32 wk), AR activity was slightly higher at low than at medium or high densities. For the first 3 harvests, analysis of variance (ANOVA) (table II) showed significant effects of sowing density on soil core AR activity, but for the subsequent 4 harvests the effect of sowing density on soil core AR activity did not reach the significance level of $P=0.05$. Averaged over all sampling times, there was a significant effect of sowing density on AR activity of medic nodule bacteria (table II).

For the late sowing date, over the first 5 harvests mean rates of AR activity increased steadily from low to high densities (fig 2) with the exception of a marked depression at harvest 3 , probably the result of a temporary water stress. Except for the first and second harvest, significant effects of sowing density on soil core AR activity were shown by ANOVA for each harvest (table III). The main effect of sowing densities across all times was highly significant.

The variation in AR activity as a function of sowing density was almost parallel to that in shoot DM production (figs 1,2 ) where AR activity had a logarithmic and shoot DM an arithmetic scale. For the early sowing date, soil core AR 


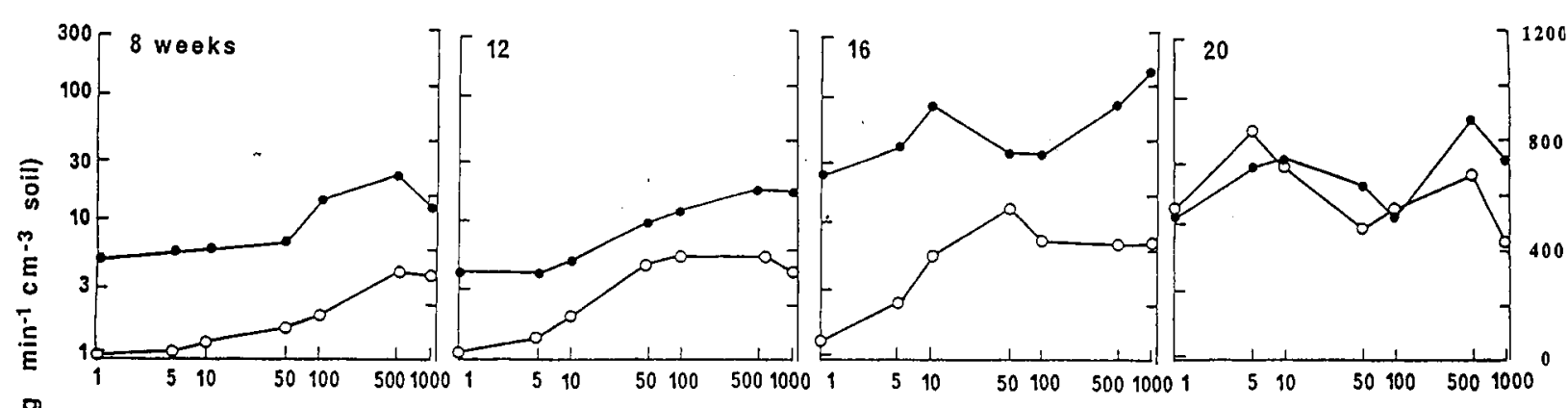

星

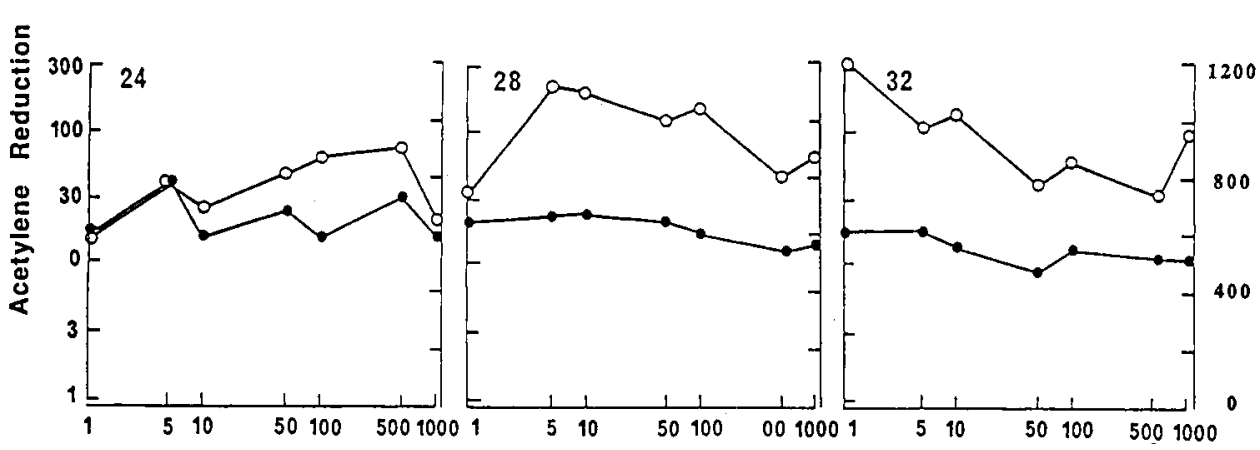

Sowing Density, (kg ha-1)

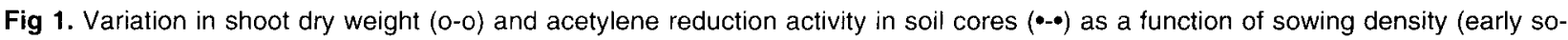
wing) at 7 times during the growing season.

Table II. Analysis of variance for acetylene reduction activity: $F$-values for the different variables (early sowing date).

\begin{tabular}{|c|c|c|c|c|}
\hline $\begin{array}{l}\text { Age from } \\
\text { sowing } \\
\text { in wk }\end{array}$ & $\begin{array}{l}A R \\
\left(\mu g \min ^{-1}\right. \\
\left.\mathrm{cm}^{-3} \text { soil }^{2}\right)\end{array}$ & $\begin{array}{l}\text { AR per } \\
\text { planta } \\
\left(\mu g \min ^{-1}\right. \\
\text { plant }\end{array}$ & $\begin{array}{c}\text { Shoot dry } \\
\text { weight } \\
\left(g \mathrm{~m}^{-2}\right)\end{array}$ & $\begin{array}{c}\text { Plant } \\
\text { populationa } \\
\left(m^{-2}\right)\end{array}$ \\
\hline
\end{tabular}

For each harvest:

$\begin{array}{rcccc}8 & 7.4^{\star \star} & 18.6^{\star \star \star} & 35.4^{\star \star \star} & 54.6^{\star \star \star} \\ 12 & 4.3^{\star} & 10.0^{\star \star \star} & 6.1^{\star \star} & 25.0^{\star \star \star} \\ 16 & 3.9^{\star} & 11.7^{\star} & 7.7^{\star} & 56.4^{\star \star \star} \\ 20 & 1.4 & 2.4 & 0.5 & 19.2^{\star \star \star} \\ 24 & 0.4 & 1.9 & 1.4 & 2.8 \\ 28 & 0.8 & 1.0 & 0.7 & 1.0 \\ 32 & 0.8 & 1.3 & 4.1^{\star} & 5.6^{\star \star}\end{array}$

For all harvests together:

$\begin{array}{lcccc}\text { Sowing } & 3.2^{\star} & 25.4^{\star \star \star} & 1.8 & 8.4^{\star \star \star} \\ \text { density } & & & & \\ \begin{array}{l}\text { Age of } \\ \text { plants }\end{array} & 14.2^{\star \star \star} & 38.5^{\star \star \star} & 57.2^{\star \star \star} & 40.6^{\star \star \star} \\ \begin{array}{l}\text { Interaction } \\ \text { (density } x \text { age) }\end{array} & 1.6^{\star} & 1.5 & 8.1^{\star \star \star}\end{array}$

${ }^{a}$ Because of the heterogeneity of the original data and the skewness in the distribution of the data, both AR values and plant population numbers were replaced by their logarithms for statistical analysis. Level of significance: ${ }^{*} P=0.05 ;{ }^{* \star} P$ $=0.01 ;{ }^{* \star} P=0.001$. activity was better correlated with the weight of DM present at the time of harvest during the vegetative period of plant growth than after flowering (table IVa). AR activity slowed down when growth had ceased at medium and high densities and became relatively greater at the low densities where swards were still growing (fig 1). The same association between AR activity and shoot DM per unit area was observed in the late-sown plants (fig 2, table IVb).

\section{Variation in acetylene reduction activity with plant age}

For the early sowing date at all sowing densities there were 2 contrasting patterns in AR activity as the plants developed: i) during the vegetative phase of development, soil core AR activity at each sowing density increased with time from sowing to reach a maximum rate of AR activity at flowering, ie at 16 wk from sowing (fig 3); ii) during the post-flowering phase there was a decline in AR activity at all sowing densities, but the decline was sharper at the high than at the lower densities. The low densities $\left(1,5\right.$ and $\left.10 \mathrm{~kg} \mathrm{ha}^{-1}\right)$ had higher AR activity at the end than at the first harvest whereas the opposite was true of the high sowing densities. 


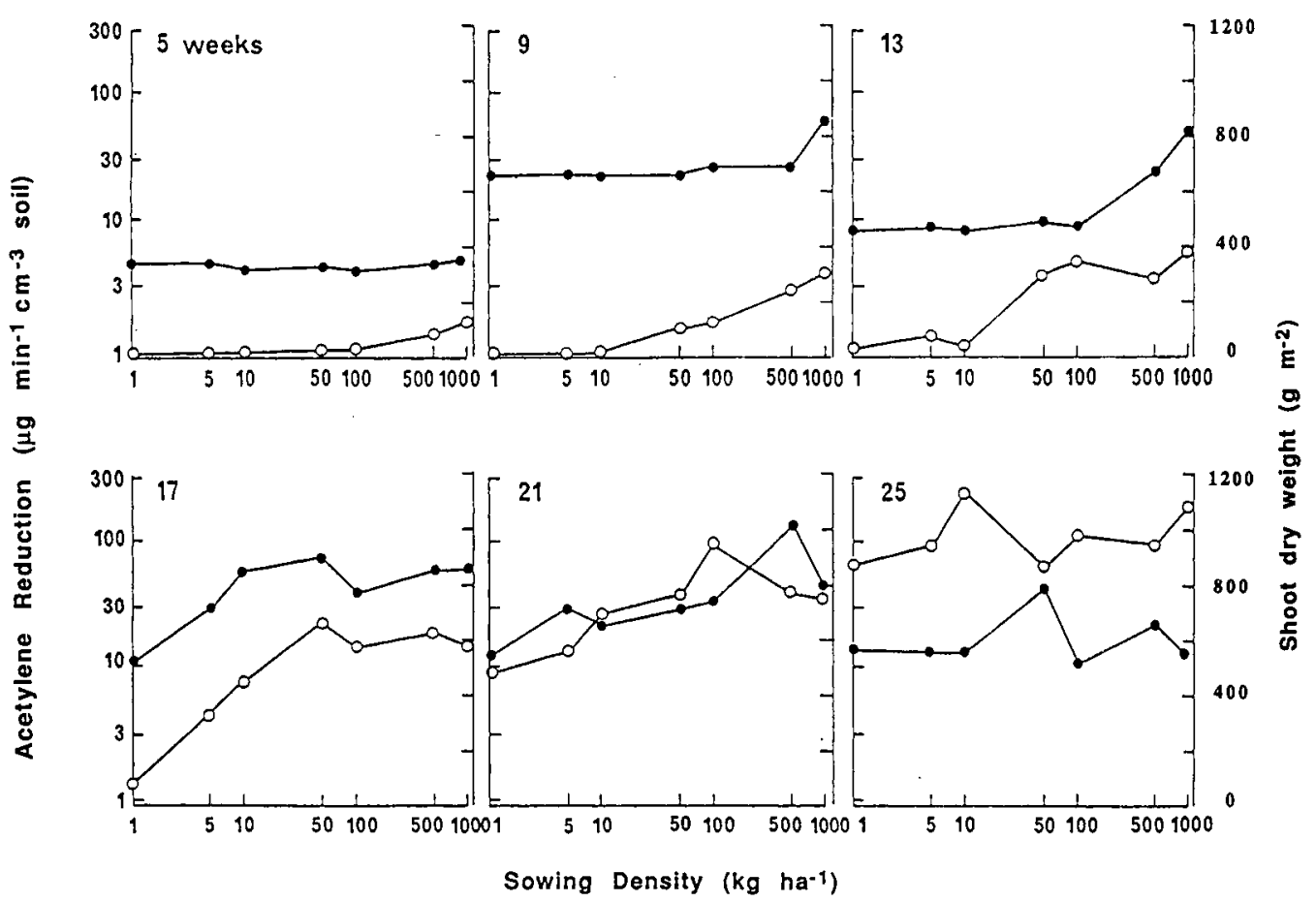

Fig 2. Variation in shoot dry weight (o-o) and acetylene reduction activity in soil cores (•-•) as a function of sowing density (late sowing) at 6 times during the growing season.

Table III. Analysis of variance for acetylene reduction activity: $F$-values for the different variables (late sowing date).

\begin{tabular}{|c|c|c|c|}
\hline $\begin{array}{l}\text { Age from } \\
\text { sowing } \\
\text { in wk }\end{array}$ & $\begin{array}{c}A R \\
\left(\mu g \min ^{-1}\right. \\
\left.c m^{-3} \text { soil }\right)^{2}\end{array}$ & $\begin{array}{l}\text { AR per } \\
\text { plant } \\
\left(\mu g \min ^{-1}\right. \\
\text { plant }\end{array}$ & $\begin{array}{l}\text { Shoot dry Plant } \\
\text { weight population } \\
\left(g m^{-2}\right) \quad\left(m^{-2}\right)\end{array}$ \\
\hline
\end{tabular}

For each harvest:

$\begin{array}{rcccc}5 & 0.5 & 157.1^{\star \star \star} & 85.6^{\star \star \star} & 132.4^{\star \star \star} \\ 9 & (2.7)^{\mathrm{b}} & 16.7^{\star \star \star} & 20.3^{\star \star \star} & 26.1^{\star \star \star} \\ 13 & 8.1^{\star \star} & 13.2^{\star \star \star} & 20.3^{\star \star \star} & 26.1^{\star \star \star} \\ 17 & 1.7 & 6.3^{\star \star \star} & 4.2^{\star} & 50.8^{\star \star \star} \\ 21 & 3.2^{\star} & 1.3 & (2.9)^{\mathrm{c}} & 3.0^{\star} \\ 25 & (2.9)^{\mathrm{c}} & 1.3 & 0.5 & 2.0\end{array}$

For all harvest together:

$\begin{array}{lrrrr}\text { Sowing } & 11.99^{\star \star \star} & 7.25^{\star \star \star} & 23.3^{\star \star \star} & 51.5^{\star \star \star} \\ \text { density } & & & & \\ \text { Age of plants } & 40.9^{\star \star \star} & 50.2^{\star \star \star} & 141.3^{\star \star \star} & 31.1^{\star \star \star} \\ \text { Interaction } & 2.1^{\star \star} & 5.7^{\star \star \star} & 5.0^{\star \star \star} & 5.8^{\star \star \star} \\ \text { (density } x \text { age) } & & & \end{array}$

a Data for AR values and plant population numbers were transformed into logarithm for statistical analysis; $(2.7)^{\mathrm{b}}$ $P=0.065 ;(2.9)^{c} P=0.054$. Levels of significance: ${ }^{\star} P=0.05$; ${ }^{\star *} P=0.01 ;{ }^{\star \star *} P=0.001$.
Table IV. Coefficients of correlation between soil core $A R$ rates and plant growth parameters.

\begin{tabular}{|c|c|c|c|}
\hline $\begin{array}{l}\text { Age of } \\
\text { plants }\end{array}$ & $\begin{array}{c}\text { Shoot } \\
\text { dry weight }\end{array}$ & $\begin{array}{c}\text { Plant } \\
\text { population }\end{array}$ & $\begin{array}{l}\text { Relative } \\
\text { growth rate }\end{array}$ \\
\hline
\end{tabular}

Early sowing date

$\begin{array}{rlll}8 & 0.64^{\star \star} & 0.75^{\star \star} & -0.56^{\star \star} \\ 12 & 0.87^{\star \star \star} & 0.80^{\star \star \star} & -0.23 \mathrm{NS} \\ 16 & 0.46^{\star} & 0.58^{\star} & -0.23 \mathrm{NS} \\ 20 & 0.62^{\star \star} & 0.53^{\star} & -0.02 \mathrm{NS} \\ 24 & 0.47^{\star} & 0.31 \mathrm{NS} & -0.09 \mathrm{NS} \\ 28 & 0.47^{\star} & 0.21 \mathrm{NS} & -0.31 \mathrm{NS} \\ 32 & 0.50^{\star} & 0.18 \mathrm{NS} & 0.21 \mathrm{NS}\end{array}$

Late sowing date

$\begin{array}{rlll}5 & 0.42^{\star} & 0.25 \mathrm{NS} & - \\ 9 & 0.65^{\star \star \star} & 0.58^{\star \star} & -0.19 \mathrm{NS} \\ 13 & 0.60^{\star \star} & 0.68^{\star \star} & -0.56^{\star \star} \\ 17 & 0.74^{\star \star \star} & 0.59^{\star \star} & 0.11 \mathrm{NS} \\ 21 & 0.50^{\star} & 0.46^{\star} & -0.48 \mathrm{NS} \\ 25 & 0.14 \mathrm{NS} & 0.47^{\star} & -0.16 \mathrm{NS}\end{array}$

Level of significance: * $P=0.05 ;{ }^{\star \star} P=0.01 ;{ }^{* \star \star} P=0.001$; NS: not significant at $P=0.05$. 


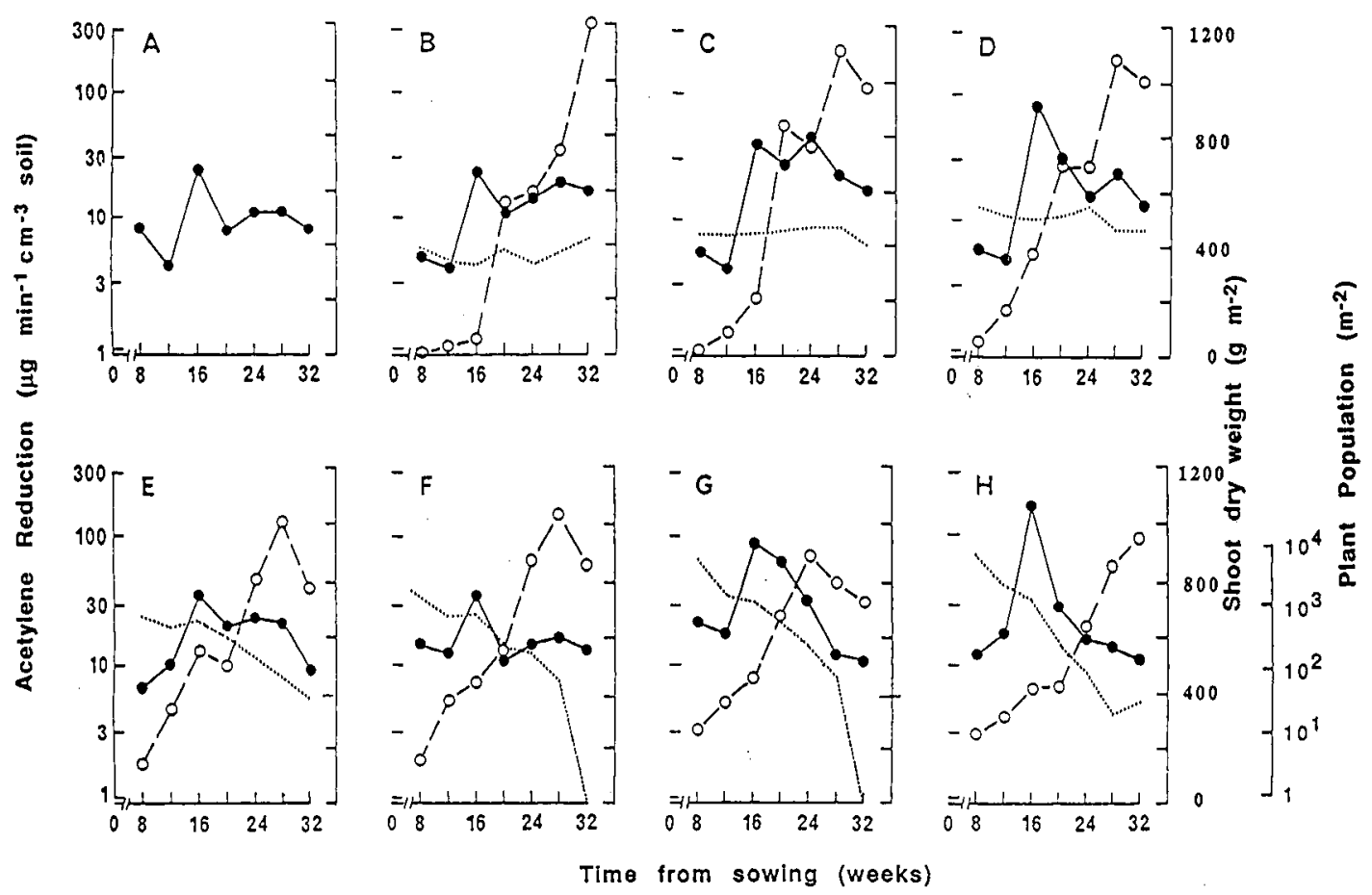

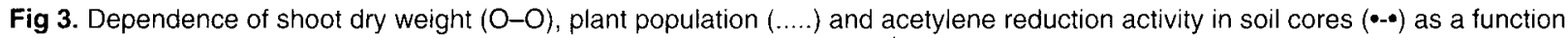
of plant age (early sowing) for the 8 sowing densities $\mathrm{A}-\mathrm{H}\left(0-1000 \mathrm{~kg} \mathrm{ha}^{-1}\right.$ seed; see Methods).

The effect of plant age on the relationship between AR activity and sowing density is summarized in figure 4 where the slopes of simple regressions of mean rates of AR activity on sowing densities for each harvest have been plotted against time. This figure emphasizes that soil core AR activity increased in relation to sowing densities from sowing to flowering. The relationship then decreased steeply to near zero.

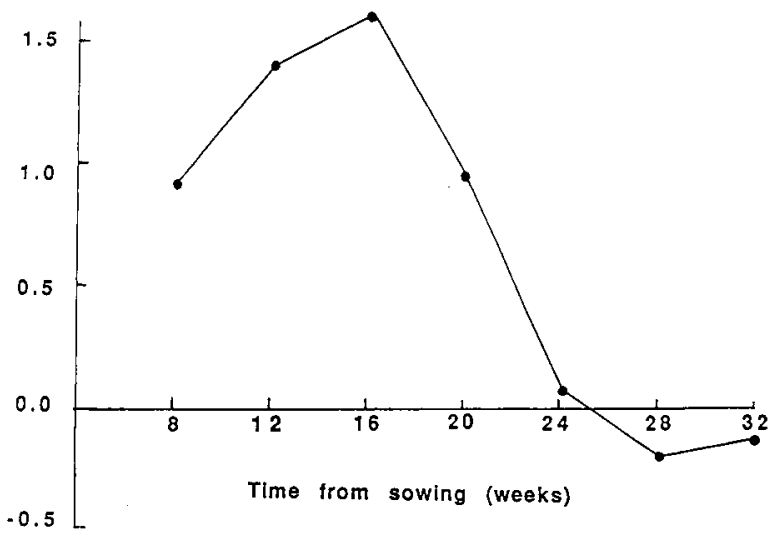

Fig 4. Slope of the regression of mean acetylene reduction activity on sowing density as a function of plant age (early sowing density). Correlation coefficients $\left(R^{2}\right)$ for wk 8 to 32 respectively are: $0.38 ; 0.59^{*} ; 0.68^{\star \star} ; 0.25 ; 0.003 ; 0.06 ; 0.04$.
For the late sowing date the same pattern of variation of $A R$ activity with plant age was observed (fig 5). At full flowering (17 wk from sowing) a sharp increase in soil core AR activity occurred at all sowing densities. At 21 wk from sowing (pod-filling stage) the mean rates of $A R$ activity declined again with the exception of the sowing density of $500 \mathrm{~kg} \mathrm{ha}^{-1}$ where 1 of the replicates had a much higher AR activity $(47 \mu \mathrm{g}$ $\mathrm{min}^{-1} \mathrm{~cm}^{-3}$ soil) than the others.

Irrespective of sowing date, the post-flowering decline in AR activity coincided with a sharp decrease in plant production mainly at the medium and high sowing densities (figs 4,5 ). In contrast only a small variation was observed in plant population at the low densities.

The relations between AR activity, shoot dry weight and plant number per unit area in the preflowering and post-flowering periods were examined using simple regression analysis. For the early sowing date, the regression of AR activity on shoot dry weight for the pre-flowering period is described by the equation:

AR activity rate $=-1.24+0.041$, shoot dry weight $\left(R^{2}=54 \% \%^{\star \star \star}\right)$

AR activity rate $=\left(\mu \mathrm{g} \mathrm{min}^{-1} \mathrm{~cm}^{-3}\right.$ soil $)$

Shoot dry weight $=\left(\mathrm{mg} \mathrm{m}^{-2}\right)$ 


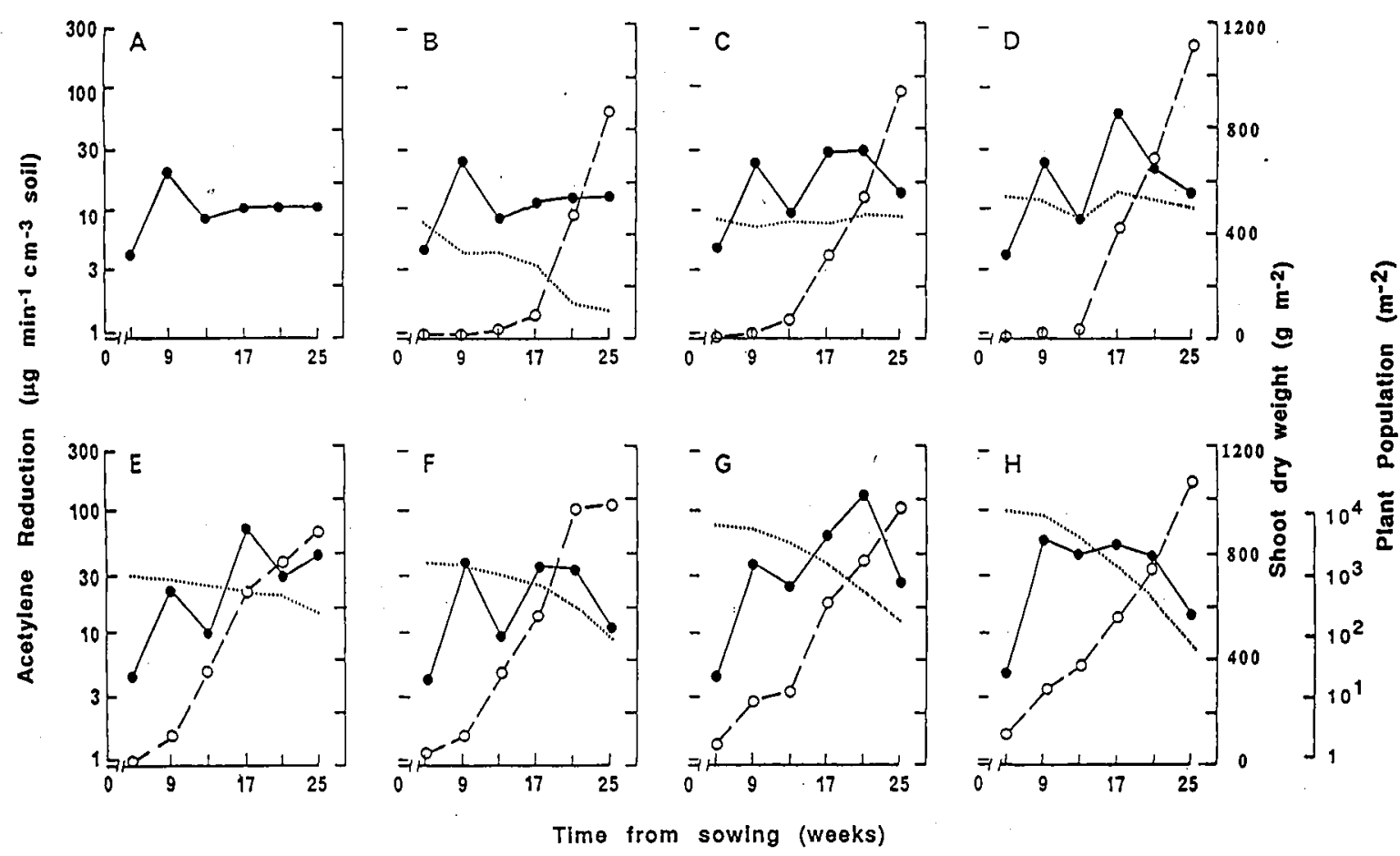

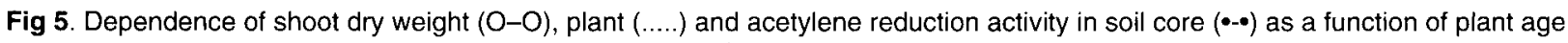
(late sowing) for the 8 sowing densities $\mathrm{A}-\mathrm{H}\left(0-1000 \mathrm{~kg} \mathrm{ha}^{-1}\right.$ seed; see Methods).

For the post-flowering period the regression was not significant at $P=0.05\left(R^{2}=0.11 \%\right)$. On the other hand, the association between AR activity and plant population per unit area was not significant for the pre-flowering period $\left(R^{2}=2 \%\right)$, but was significant for the post-flowering period although the coefficient of determination was still low:

AR activity rate $=0.49+0.18$, plant population $\left(R^{2}=30 \%{ }^{\star \star \star}\right)$

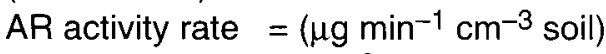

Plant population $=\left(\mathrm{m}^{-2}\right)$

The $R^{2}$ was low because 1 density $(F=100 \mathrm{~kg}$ $\mathrm{ha}^{-1}$ ) seemed anomalous.

Similar results were obtained for the late sown plants with the same $R^{2}\left(53 \%{ }^{* * *}\right)$ for the relation between AR activity and shoot dry weight at the vegetative period of plant growth (up to $17 \mathrm{wk}$ from sowing), and with a better $R^{2}\left(52 \%{ }^{\star \star \star}\right)$ for the relation between AR activity and plant population in the post-flowering period.

\section{DISCUSSION}

Although the present study deals with the instantaneous rate of $A R$ rather than with net seasonal inputs of $\mathrm{N}$ into the soil, the average rate of soil core AR activity over the whole season and at all sowing densities (tables $\mathrm{Va}, \mathrm{b}$ ) tended to support the hypothesis advanced, namely that higher inputs of $\mathrm{N}$ occur under high medic densities than under low medic densities. However, there was a superimposed effect of age of plants on the rate of AR activity by the various sowing densities which led towards the end of the season to a change in the relationship between sowing densities and the rates of soil core AR activity. Of course, the rates of soil core AR activity had declined so much after flowering at all sowing densities that over all times, medium and high densities had higher average rates of AR activity than low densities.

The increase in the rates of soil core AR activity at all sowing densities during the vegetative period of plant development (ie, from sowing to flowering) probably reflects the increase in nodule number per unit area at each density and the increase in the supply of carbohydrates from the developing shoots. This is consistent with the concept that symbiotic $\mathrm{N}_{2}$-fixation depends primarily on current photosynthate for an energy source. Newbould (1982) indicated that clover abundance is a primary determinant of the amount of $\mathrm{N}_{2}$ fixed by clover pasture. The slight decrease in AR activity observed under all den- 
Table V. Mean values of acetylene reduction rate $\left(\mu \mathrm{g} \mathrm{min}^{-1} \mathrm{~cm}^{-3}\right.$ soil) for the field experiment.

\begin{tabular}{|c|c|c|c|c|c|c|c|c|c|}
\hline \multirow{2}{*}{$\begin{array}{l}\text { Age of } \\
\text { plants } \\
\text { in wk }\end{array}$} & \multirow[b]{2}{*}{0} & \multirow[b]{2}{*}{1} & \multirow[b]{2}{*}{5} & \multicolumn{3}{|c|}{ Sowing density $\left(\mathrm{kg} \mathrm{ha} \mathrm{a}^{-1}\right)$} & \multirow[b]{2}{*}{500} & \multirow[b]{2}{*}{1000} & \multirow[b]{2}{*}{ Mean } \\
\hline & & & & 10 & 50 & 100 & & & \\
\hline \multicolumn{10}{|c|}{ Early sowing date } \\
\hline 8 & 3.33 & 1.94 & 2.10 & 2.24 & 2.56 & 6.02 & 10.17 & 4.78 & 4.14 \\
\hline 12 & 1.58 & 1.50 & 1.50 & 1.92 & 4.00 & 7.58 & 8.08 & 7.67 & 4.23 \\
\hline 16 & 9.00 & 9.33 & 15.67 & 11.17 & 14.00 & 14.00 & 34.67 & 69.00 & 23.25 \\
\hline 20 & 3.00 & 4.67 & 15.50 & 11.75 & 9.33 & 4.00 & 28.00 & 19.83 & 12.79 \\
\hline 24 & 4.00 & 7.00 & 32.17 & 6.00 & 13.83 & 5.67 & 33.33 & 6.67 & 13.58 \\
\hline 28 & 4.17 & 8.00 & 12.33 & 10.17 & 8.83 & 6.75 & 4.67 & 5.00 & 7.52 \\
\hline 32 & 3.17 & 10.25 & 6.93 & 5.17 & 3.50 & 5.00 & 4.33 & 4.33 & 5.34 \\
\hline Mean & 4.04 & 6.10 & 12.31 & 6.44 & 8.01 & 6.96 & 17.61 & 16.84 & 9.86 \\
\hline \multicolumn{10}{|c|}{ Late sowing date } \\
\hline 5 & 1.50 & 1.67 & 1.67 & 1.58 & 1.67 & 1.58 & 1.67 & 1.83 & 1.65 \\
\hline 9 & 9.00 & 9.00 & 9.00 & 9.00 & 9.00 & 22.00 & 16.53 & 22.50 & 13.48 \\
\hline 13 & 3.17 & 3.17 & 3.33 & 3.17 & 4.00 & 3.50 & 11.17 & 22.67 & 6.77 \\
\hline 17 & 4.00 & 4.17 & 12.00 & 30.83 & 41.17 & 14.83 & 31.67 & 30.00 & 21.08 \\
\hline 21 & 4.00 & 4.50 & 15.33 & 11.67 & 22.50 & 13.25 & 70.00 & 19.83 & 20.34 \\
\hline 25 & 4.00 & 5.58 & 5.17 & 5.42 & 19.17 & 4.25 & 10.73 & 6.08 & 7.55 \\
\hline Mean & 4.28 & 4.68 & 7.68 & 10.28 & 15.88 & 9.71 & 23.68 & 17.15 & 11.68 \\
\hline
\end{tabular}

sities at 12 wk from (early) sowing probably was due to water stress as a result of a dry period between sampling 1 and 2 (table I). This decrease in AR activity is consistent with the results of the soil fertility survey (Dahmane 1978) which indicated a lower soil $\mathrm{N}$ accumulation in a dry season.

The higher the AR activity at the medium and high sowing densities observed during the vegetative period of plant growth is associated with increased leaf area index and probable increases in number of nodules per unit area at these higher densities. At the early stage of plant growth during which the rate of photosynthesis increased linearly with the leaf area index up to a ceiling value ( 7 for subterranean clover according to Silsbury and Fukai, 1977) the increased rate of $A R$ activity can probably be explained by a greater supply of carbohydrates (per $\mathrm{m}^{2}$ ) to the associated bacteria at the higher leaf area index at the medium and high sowing densities.

In the present study, the sharp decrease in AR activity recorded at $20 \mathrm{wk}$ from sowing in the early sown plots was perhaps accentuated by wet soil conditions and overcast weather at the time of sampling. This is supported by the same decrease observed under the control $\left(0 \mathrm{~kg} \mathrm{ha}^{-1}\right.$ sowing density) and by a similar decrease in $A R$ activity of soil cores from the late sown plots which had not reached flowering at the date (13 wk from sowing). However, AR activity of the early sown plots continued to decrease confirming the general decline in AR activity which started after flowering.

The post-flowering decline in AR activity, observed at all sowing densities of medic agrees with that reported for pea (Pisum sativum) (La Rue and Kurz, 1973) and for soybean (Lawn and Brun, 1974) although for soybean the decline started a little later (at the pod-filling stage). A similar pattern of $\mathrm{N}_{2}$-fixation by white clover was observed by Masterson and Murphy (1976) and, Bessey and Patriquin (1984). This post-flowering decline in AR activity of certain legumes has been attributed to several factors. Bond (1936) suggested that the efficiency of $\mathrm{N}_{2}$-fixation (ie the ratio of $\mathrm{N}_{2}$ fixed to the dry weight of nodules) decreased with age because of the supply of carbohydrates per bacterium decreased or the number of inactive cells increased. Pate (1958a, b) observed that plant flowering (Pisum arvense $L$ and Vicia sativa $L$ ) occasioned heavy losses in nodule number and total nodule weight and promoted emptying of the nodule. Lawn and Brun (1974), using treatments designed to alter the photosynthate supply to the nodules concluded 
that there was a limitation to symbiotic $\mathrm{N}_{2}$-fixation by competition for photosynthates from developing pods of soybeans. For medics, the postflowering decline in soil core AR activity at all densities was found to be slightly correlated with a decrease in plant population per unit area. The continual increase in shoot DM beyond flowering was predominantly due to filling of medic pods which competed with root nodules for the available carbohydrates.

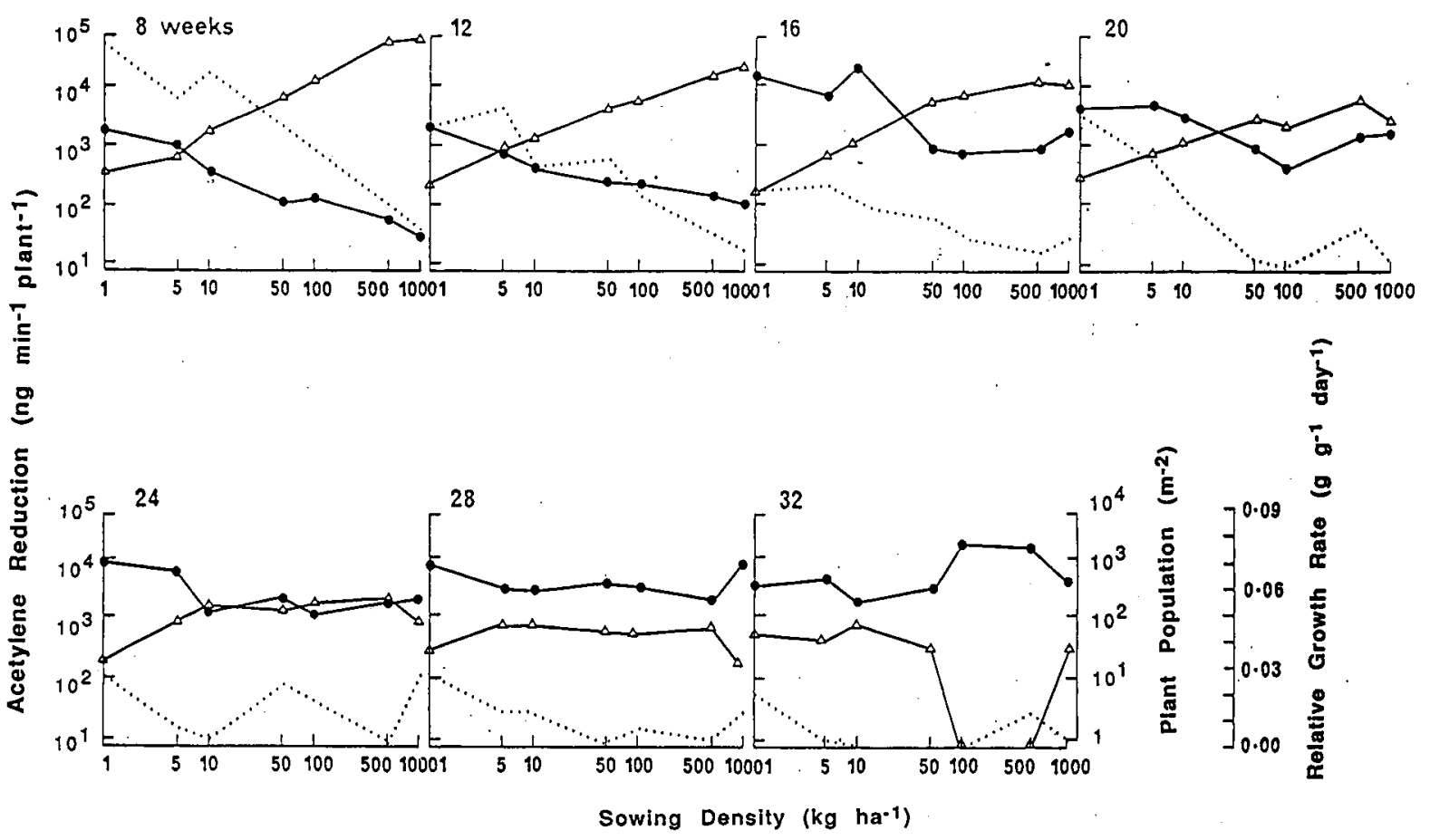

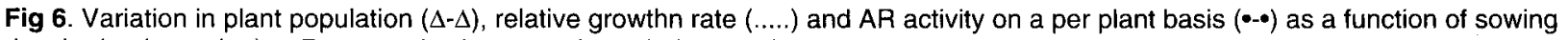
density (early sowing) at 7 successive harvests through the growing season.

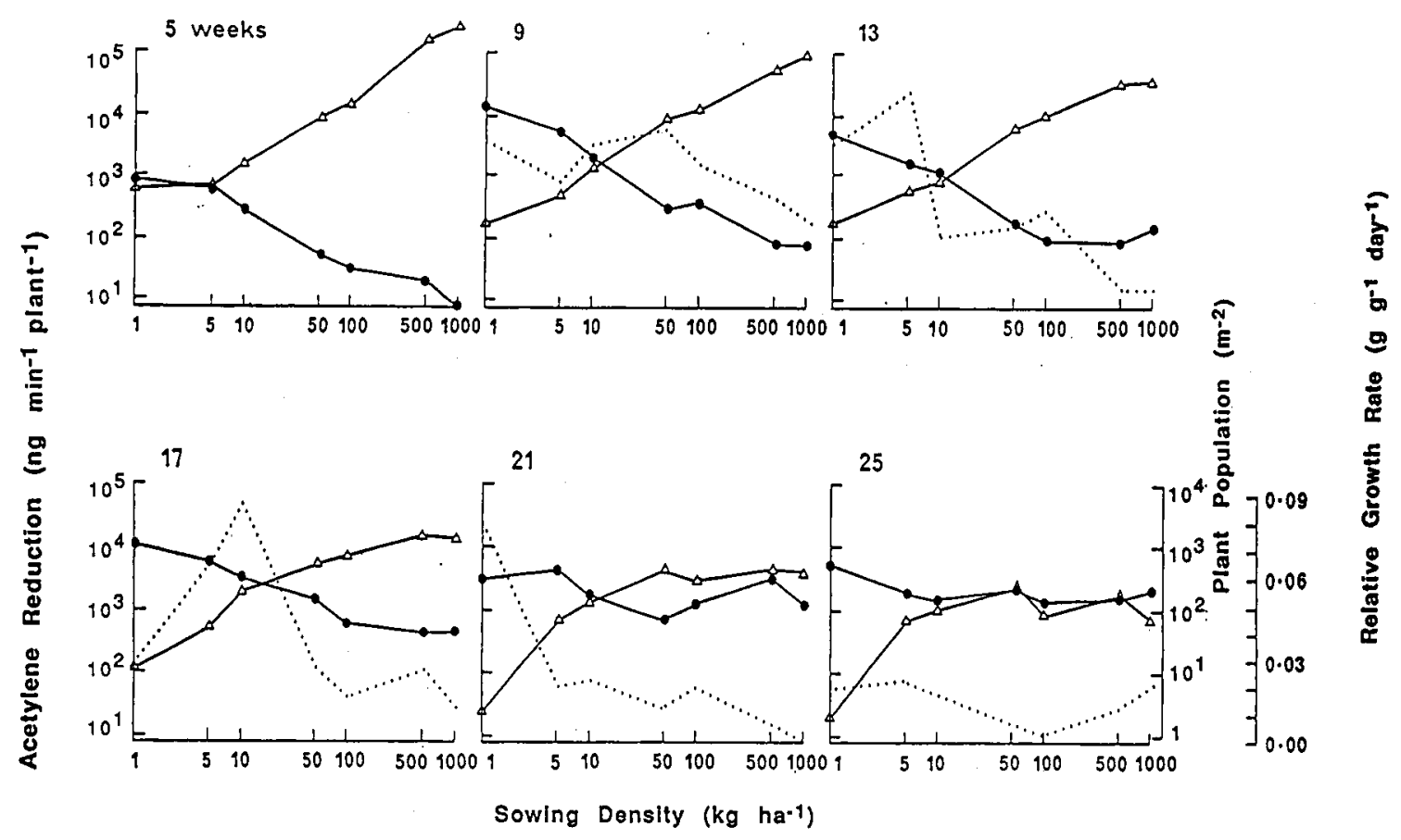

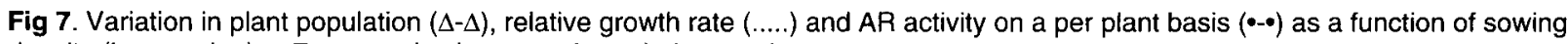
density (late sowing) at 7 successive harvests through the growing season. 
Table VI. Coefficient of correlations between acetylene reduction rate per plant (ng $\mathrm{min}^{-1}$ ) and plant population, and plant relative growth rate at different harvests.

\begin{tabular}{clc}
\hline $\begin{array}{l}\text { Age of plants } \\
\text { in wk }\end{array}$ & $\begin{array}{c}\text { Plant } \\
\text { population }\end{array}$ & $\begin{array}{c}\text { Relative } \\
\text { growth rate }\end{array}$ \\
\hline Early sowing date & & \\
8 & $-0.96^{\star \star \star}$ & $0.45^{\star}$ \\
12 & $-0.89^{\star \star \star}$ & $0.32 \mathrm{NS}$ \\
16 & $-0.90^{\star \star \star}$ & $0.40 \mathrm{NS}$ \\
20 & $-0.58^{\star}$ & $0.60^{\star \star}$ \\
24 & $-0.62^{\star \star}$ & $-0.10 \mathrm{NS}$ \\
28 & $-0.89^{\star \star \star}$ & $0.39 \mathrm{NS}$ \\
32 & $-0.76^{\star \star \star}$ & $0.01 \mathrm{NS}$ \\
& & \\
Late sowing date & & - \\
5 & $-0.99^{\star \star \star}$ & $0.14 \mathrm{NS}$ \\
9 & $-0.98^{\star \star \star}$ & $0.45^{\star}$ \\
13 & $-0.94^{\star \star \star}$ & $0.31 \mathrm{NS}$ \\
17 & $-0.85^{\star \star \star}$ & $0.12 \mathrm{NS}$ \\
21 & $-0.42 \mathrm{NS}$ & $0.03 \mathrm{NS}$ \\
25 & $-0.60^{\star \star}$ & \\
\hline
\end{tabular}

Level of significance: * $(P=0.05)$; ${ }^{* \star}(P=0.01)$; ${ }^{* \star}$ $(P=0.001)$; NS: non-significant at $P=0.05$.

Interpretation of the results of the experiment is clarified if AR activity is expressed on a per plant basis. At each harvest, AR activity per plant was higher where plant population was lower (figs 6,7). This negative association was found to be highly significant throughout the growing season (table VI a, b). During the vegetative period of plant growth and at both early and late sowing dates, AR activity per plant at all densities increased steadily, whereas beyond flowering the rate of $A R$ per plant tended to decrease or remain constant depending on the sowing density. The reduction in plant population per unit area at each successive harvest tended to be associated with an increase in plant relative growth rate. Thus, the results suggest that during the pre-flowering period the decrease in plant population resulted in better growth of individual plants owing to less competition for light, water and nutrients, and led to a higher supply of carbohydrates per nodule bacterium which increased their rate of AR. After flowering, the decrease in plant population was not supported by a high supply of carbohydrates to the nodules due to the formation of new non-photosynthetic tissues which competed for available carbohydrates. A high demand for $\mathrm{N}$ at the pod-filling stage has been reported for soybeans by Latimore et al (1977), but this did not stimulate $\mathrm{N}_{2}$ fixation; on the contrary, they observed a decline in $\mathrm{N}_{2}$-fixation at the pod-filling stage. Our results suggest that, in practice, to ensure a moderate to high level of $\mathrm{N}$-input into the soil during the pasture phase of the ley farming system, the number of medic plants per square meter $\left(\mathrm{m}^{2}\right)$ should be equal to that obtained with $20 \mathrm{~kg} \mathrm{ha}^{-1}$ sowing density (eg, 500 plants $\mathrm{m}^{-2}$ ). However, it is likely that under farm conditions, the number of germinating and viable medic seeds per unit area surviving to form a pasture is often lower than the 500 optimum indicated, leading to suboptimal $\mathrm{N}$ fixation. Therefore, seed bank reserves of selfregenerating medic species should be considered to achieve high to moderate densities of medics which are needed early in the season to ensure both purposes of winter herbage production and $\mathrm{N}$ inputs into the soil. As mentioned by Cocks (1988), pasture production depends on plant numbers, especially in winter, and plant population itself is dependent on seed production, survival and dormancy. Pasture management, namely grazing intensity or stocking rate, superphosphate application and weed control have direct effects on seed production by medics and thereafter on seed bank reserves maintained in the soil (ICARDA annual report, 1992).

In the present experiment, medics were not grazed or defoliated. Light grazing of medic pasture at the early stages of plant growth can be expected to extend the period of vegetative growth by maintaining the rate of appearance of young leaves for longer periods (Donald, 1963), and presumably enhance the inputs of $\mathrm{N}$ by medics to the soil. Masterson and Murphy (1976) mentioned that total annual fixation could be significantly increased if flowering could be either prevented, postponed or controlled.

The higher rates of $\mathrm{N}$ fixation of medic plants during the vegetative phase has a consequence for pasture management. The effect of grazing in delaying flowering may be important in the overall seasonal $\mathrm{N}$ fixation by a pasture. This requires study and may lead to mixtures of early and late flowering cultivars of Medicago truncatula eg, early Cyprus and Jemalong, which could extend the vegetative period of growth of the mixed pasture and lead to higher $\mathrm{N}$ inputs per unit area.

It is of interest to note that soil core AR activity at $0 \mathrm{~kg} \mathrm{ha}^{-1}$ is as high as that of $1 \mathrm{~kg} \mathrm{ha}^{-1}$ seed, indicating measurable non-symbiotic fixation of $\mathrm{N}_{2}$ by free-living bacteria. 


\section{ACKNOWLEDGMENTS}

The authors thank CM Rivers and JS Ascher for expert technical assistance and the Wheat Research Commitee of South Australia for financial support. ABK Dahmane acknowledges the support of a CIMMYT and Ford Foundations scholarship.

\section{REFERENCES}

Alstron AM, Graham RD (1982) The influence of soil nitrogen status and previous crop on nitrogen fixation (acetylene reduction) in barrel medic, Medicago truncatula Gaertn. Aust J Soil Res 20, 51-59

Bond $G$ (1936) Quantitative observations on the fixation and transfer of nitrogen in the soybean, with special reference to the mechanism of transfer of fixed nitrogen from bacillus to host. Ann Bot 50, 559-578

Brock JL (1973) Growth and nitrogen fixation of pure stands of three pasture legumes with high/low phosphate. NZJ Agric Res 16, 483-491

Cocks PS (1988) The role of pasture and forage legumes in livestock based farming systems. In: Nitrogen Fixation by Legumes in Mediterranean Agriculture: Developments in Plant and Sciences (DP Beck, LA Materon, eds) Martinus Nijhoff Publishers, Dordrecht 3-10

Dahmane ABK (1978) The influence of soil, climatic and management factors on nitrogen accretion by annual Medicago species in a semi-arid environment of PhD thesis, Univ Adelaide, S Australia

Donald CM (1963) Competition among crop and pasture plants. Adv Agron 15, 1-118

Halliday J, Pate JS (1976) The acetylene reduction assay as a means of studying nitrogen fixation in white clover under sward and laboratory conditions. J Br Grass/ Soc 31, 29-35

Hopmans P, Chalk PM, Douglas LA (1983) Symbiotic nitrogen fixation by legumes growing in pots. II. Uptake of ${ }^{15} \mathrm{~N}$-labelled $\mathrm{NO}_{3}, \mathrm{C}_{2} \mathrm{H}_{2}$ reduction and $\mathrm{H}_{2}$ evolution by Trifolium subterranneum L, Medicago truncatula Gaertn and Acacia dealbata Link. Plant Soil 74, 333-342

ICARDA International center for agricultural research in the dry areas (1992) Annual Report on Pasture, Forage and Livestock Program

La Rue TAG, Kurtz WGW (1973) Estimation of nitrogenase using a colorimetric determintation for ethylene. Can J Microbiol 19, 304-305

Latimore M, Giddens Jr J, Ashley DA (1977) Effect of ammonium and nitrate nitrogen upon photosynthate supply and nitrogen fixation by soybean. Crop Sci $17,39-404$

Lawn RJ, Brun WA (1974) Symbiotic nitrogen fixation in soybeans. I. Effect of photosynthetic source-sink manipulations. Crop Sci 14, 11-16
Masterson CL, Murphy PM (1976) Application of the acetylene reduction technique to the study of nitrogen fixation by white clover in the field. In: Symbiotic Nitrogen Fixation in Plants (Nutman PS, ed) Cambridge Univ Press, Cambridge, UK, 229-318

Newbould P (1982) Biological nitrogen fixation in upland and marginal areas of the United Kingdom. Phil Trans $R$ Soc Lond B Biol Sci 296, 405-417

Northcote KH (1971) A Factual Key For the Recognition of Australian Soils. Rellim Tech Publi, Glenside, S Australia

Pate JS (1958a) Nodulation studies in legumes. I. The synchronization of host and symbiotic development in the field pea, Pisum arvense L. Aust $J$ Biol Sci 11, 366-381

Pate JS (1958b) Nodulation studies in legumes. II. The influence of various environmental factors on symbiotic expression in the vetch (Vicia sativa $\mathrm{L}$ ) and other legumes. Aust J Biol Sci 11, 496-515

Ruegg JJ, Alston AM (1978) Seasonal and diurnal variation of nitrogenase activity (acetylene reduction) in barrel medic (Medicago truncatula Gaertn) grown in pots. Aust J Agric Res 29, 951-962

Silsbury JG, Adem L, Baghurst P, Carter ED (1979) A quantitative examination of the growth of swards of Medicago truncatula cv Jemalong. Aust J Agric Res 30, 53-63

Silsbury JH, Fukai S (1977) Effects of sowing time and sowing density on the growth of subterranean clover at Adelaide. Aust J Agric Res 28, 427-440

Sinclair AG (1974) Measurements of atmospheric nitrogen fixation in legume-based pasture turfs using the acetylene reduction assay. $N Z J$ Agric Res 18, 189-195

Sinclair AG, Hannagan RB, Risk WH (1976) Evaluation of the acetylene reduction assay of nitrogen fixation in pastures using small soil-core samples. $N Z J$ Agric Res 19, 451-458

Turner GL, Gibson AH (1980) Measurement of nitrogen fixation by indirect means. In: Methods for Evaluating Biological Nitrogen Fixation (Bergerson FJ, ed) John Wiley and Sons Ltd, NY

Vessey JK, Patriquin DG (1984) In situ nitrogen fixation by white clover in mixed swards in Nova Scotia. Can J Plant Sci 64, 625-636

Wery J, Deschamps M, Leger-Cresson N (1988) Influence of some agroclimatic factors and agronomic practices on nitrogen nutrition of chickpea (Cicer arictinum L). In: Nitrogen Fixation by Legumes in Mediterranean Agriculture: Developments in Plant and Sciences (DP Beck, LA Materon, eds) Martinus Nijhoff Publishers, Dordrecht, 287-301

Witty JF, Minchin FR (1988) Measurement of nitrogen fixation by the acetylene reduction assay; myths and mysteries. In: Nitrogen Fixation by Legumes in Mediterranean Agriculture: Developments in Plant and Sciences (DP Beck, LA Materon, eds) Martinus Nijhoff Publishers, Dordrecht, 331-344 